7. Сарна A. Noise \& smart: от города шумного — к «умному». TOPOS: PS Soundscapes. Вильнюс, 2018. № 1. C. $148-158$.

8. Соболевская О.В. Звуковой ландшафт. Что такое sound studies и как они помогают понять город. IQ.HSE. URL: https://.ru/news/227703157.html (дата звернення 19.10.2019) 20.02.2019)

9. 40sorok. Pripjat'. Soundcloud. URL: https://soundcloud.com/34magnet/40sorok-pripjat (дата звернення: 16.01.2019).

10. Cusack P. Sounds from dangerous Places. URL: https://tinyurl.com/yagvxmg2 (дата звернення:

11. David New. Listen. NFB. URL: http://www.nfb.ca/film/listen/ (дата звернення: 16.01.2019). 27.01.2019).

12. Kirkegaard Jacob. AION : Fonik Works. URL: https://fonik.dk/works/aion.html. (дата звернення:

13. London Sound Survey. URL: https://www.soundsurvey.org.uk/ (дата звернення: 27.01.2019).

14. Schafer R. Murrey. A Sound Education. 100 Exercises in Listening and Sound-Making. Ontario : Arcana Editors, 1992. 144 p.

\title{
References
}

1. Boholiubova, I.V. (2019). Urban Cultural Studies: to hear the image of the city. Notes of art criticism, 35, 83-89. [in Ukrainian].

2. Bolshakov, V.P. (2017) Cultural practices of aesthetic and artistic mastering of the world by man. Bulletin of SPbGUKI, 1 (30) March, 36-39. [in Russian].

3. Bratochkin A. Work with the past in urban space: the specifics of Belarus. (2015). European cafe. Retrieved from http://eurocafe.by/lecture/2015/06/07/rabota-s-proshlym-v-gorodskom-prostranstve-specifika-belarusi. [in Russian].

4. Butsko A. (2012). Music of Chernobyl and sounds of Berlin. Dw. Retrieved from https://tinyurl.com/ya8fn7hh. (date of address: 15.01.2019). [in Russian].

5. Lucier, E. (2017). I am sitting in a room. MIHM. Trajectory of Music. Retrieved from https://www.youtube.com/watch?v=hsoK2HILI_g. [in English]

6. Roman S. (2016). The film "Around Belarus on bicycles with motors." Ulj. Retrieved from https://ulej.by/project?id=78105. [in Russian] [in Russian].

7. Sarna A. (2018). Noise \& Smart: From a Noisy to a «Smart» City. TOPOS: PS Soundscapes, 1, 148-158.

8. Sobolevskaya O.V. Sound landscape. What is sound studies and how they help to understand the city. IQ.HSE. Retrieved from https://.ru/news/227703157.html [in Russian]. [in English].

9. 40sorok. (2017). Pripjat'. Soundcloud. Retrieved from https://soundcloud.com/34magnet/40sorok-pripjat.

10. Cusack, P. Sounds from dangerous Places. Retrieved from https://tinyurl.com/yagvxmg2. [in English].

11. New, D. (2009). Listen. NFB. Retrieved from http://www.nfb.ca/film/listen/ [in English]. English].

12. Kirkegaard Jacob. (2006). AION. Fonik Works. Retrieved from https://fonik.dk/works/aion.html. [in

13. London Sound Survey. Retrieved from https://www.soundsurvey.org.uk/. [in English].

14. R. Murray Schafer. (1992) A Sound Education. 100 Exercises in Listening and Sound-Making. Ontario, Canada: Arcana Editors. [in English].

Стаття надійшла до редакиії 12.08.2019

Прийнято до публікаиії 10.09.2019

УДК $130.2: 392.5(477.8)+7.046 .1$

Соболсвська Світлана Олександрівна, аспірантка кафедри культурології та інформаційних комунікацій Національної академії керівних кадрів культури і мистецтв lana2930@bigmir.net

ORCID 0000-0002-5361-7085

\section{МЕТОДОЛОГІЧНІ ЗАСАДИ ДОСЛІДЖЕННЯ КУЛЬТУРОТВОРЧОЇ ФУНКЦЇ̈ УКРАЇНСЬКОГО АМАТОРСЬКОГО ТЕАТРУ (КІНЕЦЬ ХХ - ПОЧАТОК ХХІ СТОЛІТТЯ)}

Мета роботи - сформувати методологічну базу дослідження культурного феномену українського аматорського театру в кінці XX - на початку XXI століття, його культуротворчої функції та впливу на формування особистості митця. Методологія дослідження включає в себе хронологічний метод для аналізу діяльності і впливу аматорських театрів на суспільні процеси, метод конкретизації для вивчення стану

(C) Соболєвська С.O., 2019 
мистецької й культуротворчої діяльності аматорських театрів у зв’язку з певними умовами існування та історичного розвитку. Наукова новизна полягає в тому, що вперше у культурологічній інтерпретації дається визначення поняття «аматорський театр» та розробляється методологія дослідження культуротворчої функції українського аматорського театру. Висновки. Методологічною основою дослідження культуротворчої функції українського аматорського театру та його ролі в становленні особистості митця у кінці XX - на початку XXI століття має бути системно-комплексний підхід, у контексті якого важливо з'ясувати культуротворчу функцію сучасного аматорського театру й виявити причинно-наслідкові зв'язки між процесом становлення особистості митця в сучасному суспільстві, що динамічно розвивається, та низкою інших фундаментальних утворень, що виникають під час вивчення проблеми. Отже, необхідно якомога повніше використати той методологічний потенціал, котрий накопичено протягом останніх десятиріч у галузі культурологічного знання, щоб проілюструвати здатність сучасного українського аматорського театру, що має можливості ретрансляції практичного культурного досвіду, впливати на формування культури й становлення особистості.

Ключові слова: аматорський театр, евристичні аспекти, культура, культуротворчість, методи дослідження, особистість

Соболевская Светлана Александровна, аспирантка кафедры культурологии и информационных коммуникаций Национальной академии руководящих кадров культуры и искусств

Методологические основы исследования культуротворческой функции украинского аматорского театра (конец XX - начало XXI века)

Цель работы сформировать методологическую базу исследования культурного феномена украинского аматорского театра в конце XX - начале XXI века, его культуротворческой функции и влияния на формирование творческой личности. Методология исследования включает в себя хронологический метод для анализа деятельности и влияния аматорских театров на общественные процессы, метод конкретизации для изучения состояния творческой и культуротворческой деятельности любительских театров в связи с определенными условиями существования и исторического развития. Научная новизна заключается в том, что впервые в культурологической интерпретации дается определение понятию «аматорский театр» и разрабатывается методология исследования культуротворческой функции украинского любительского театра. Выводы. Методологической основой исследования культуротворческой функции украинского аматорского театра и его роли в становлении творческой личности в конце XX - начале XXI века должен быть системнокомплексный подход, в контексте которого важно определить культуротворческую функцию современного любительского театра и выявить причинно-следственные связи между процессом становления творческой личности в современном обществе, которое динамично развивается, и рядом других фундаментальных образований, возникающих во время изучения проблемы. Следовательно, необходимо как можно полнее использовать тот методологический потенциал, который накоплен в течение последних десятилетий в области культурологического знания, чтобы проиллюстрировать способность современного украинского любительского театра, имеющего возможности ретрансляции практического культурного опыта, влиять на формирование культуры и становления личности.

Ключевые слова: аматорский театр, эвристические аспекты, культура, культуротворчество, методы исследования, личность

Sobolevska Svitlana, Postgraduate of the culturelogy and information communications The National Academy of Culture and Arts Management

Methodological bases of studying the cultural function of the ukrainian amator theater (the end of $x x-$ the beginning of the xxi century)

The purpose of the article is to form a methodological basis for the study of the cultural phenomenon of Ukrainian amateur theater at the end of XX - early XXI century, its cultural-creating function, and influence on the formation of the creative personality. The methodology of the research includes a chronological method to analyze the activities and impact of amateur theaters on social processes, the method of concretization for the study of the creative and cultural activities of amateur theatres in connection with certain conditions of existence and historical development. The scientific novelty is in the fact that for the first time in the cultural interpretation given to the definition of «amateur theater» and developed the research methodology, cultural features of Ukrainian amateur theater. Conclusions. Methodological basis of research culture-creating function of the Ukrainian amateur theatre and its role in the formation of the creative personality in the end of XX - early XXI century must be systemically-integrated approach in whose context it is fundamental to find out culture-creating function of contemporary amateur theatre and to identify causal relationships between the process of formation of the creative personality in developing rapidly modern society, and other fundamental entities that occur during the study of the problem. Therefore, it is necessary to use as fully as possible the methodological potential that has been accumulated over the past decades in the field of cultural knowledge to illustrate the ability of modern Ukrainian amateur theater, which can relay practical, cultural experience, to influence the formation of culture and personality.

Key words: amateur theatre, heuristic aspects, culture, cultural creation, research methods, personality 
Актуальність теми дослідження. Культурний феномен аматорського театру у кінці XX - на початку XXI століття, його культуротворча функція та вплив на формування особистості митця залишається недостатньо дослідженим. Тож необхідно обрати та систематизувати методи дослідження цього феномену. Оскільки протягом останніх десятиріч в українській культурології наявні лише поодинокі праці щодо зв'язку театру й театральної культури із процесами формування особистості та іiі подальшого життя в соціумі, а дослідження українського аматорського театру стосувалися сфери інтересів театрознавства чи мистецтвознавства, виникла необхідність визначення культурологічних підходів та розробки методології дослідження в цьому напрямку. Також у культурології досі немає чіткого визначення поняття «аматорський театр».

Аналіз досліджень і публікацій. Для формування поняття «аматорський театр» у культурологічній площині використовувалися тлумачення понять «культура» й «особистість», наявні у працях вітчизняних і зарубіжних вчених, зокрема М. Аріарського, Г. Балла, С. Батракової, П. Герчанівської, В. Мєдінцева, Т. Сілаєвої, Я. Чорненького [2; 3; 4; 5; 9; 12]. Для визначення методології дослідження культуротворчої функції українського аматорського театру в кінці XX - на початку XXI століття в контексті культуротворчості -складної системи, де особистість прагне до досконалості та новаторства й за межами традиційної творчої діяльності, виникла необхідність звернутися до праць Т. Добіної, Є. Гротовського, Й. Хейзинги [6; 7; 10].

Мета дослідження - сформувати методологічну базу дослідження культурного феномену українського аматорського театру в кінці XX - на початку XXI століття, його культуротворчої функції та впливу на формування особистості митця. Дати визначення поняттю «аматорський театр» з позицій культурології.

Виклад основного матеріалу. Перш ніж розглянути й визначити методологічні засади дослідження українського аматорського театру в кінці XX - на початку XXI століття, необхідно звернутися до низки понять, що безпосередньо або опосередковано пов'язані із театром, який $\epsilon$ невід'ємною частиною національної культури, складовою соціально-культурної діяльності людини.

Дослідження ролі й місця соціально-культурної діяльності в житті людини в зазначений період можливе завдяки завершенню багатовікового процесу становлення науки про культуру культурології. У рамках даної наукової дисципліни розвиваються фундаментальна теоретична культурологія, що концентрується на обгрунтуванні загальних закономірностей виникнення, становлення та функціонування культури, і прикладна культурологія, завдання якої полягають у розкритті соціальних технологій створення сприятливого культурного середовища та дослідженні прилучення людини до досягнень зарубіжної та вітчизняної культури. Прикладна культурологія керується необхідністю розкриття механізму формування в кожній людині повсякденної, практичної культури, що забезпечує самоконтроль соціального буття та ствердження культури пізнання, праці, побуту, сімейних стосунків, ділового та неформального спілкування тощо [2]. Виокремити можна культуру дозвілля, що певною мірою стосується й аматорського театру, до якого люди звертаються у вільний від основної діяльності час.

Велику кількість тлумачень поняття «культура» можна пояснити тим, що воно широко використовується в різних галузях знання та наукових парадигмах. Але якщо обрати ті визначення, котрі вживаються у суміжних галузях науки та практики, то можна прослідкувати за поєднаннями понять «культура» й «особистість». Зокрема, за визначенням провідних українських культурологів поняття «культура» як світ творчих новацій - способів і результатів пізнання, інтелектуальних та образних рефлексій буття та його практичного перетворення 3 метою розширення обсягів виробництва, розподілу та споживання соціальних надбань [5, с. 96] - $\epsilon$ важливою сферою буття людини під час їі внутрішніх трансформацій. Для подальшого розвитку культури необхідною умовою стає виховання людини-митця, яка буде відкритою для змін і зорієнтованою на творчий пошук у всіх видах своєї діяльності, на продукування культурних цінностей. Адже створення культурних цінностей визначається функціональними особливостями й конструктивними параметрами, що пов'язані з мінливістю способів та умов їх появи, ідейними спонуканнями їхніх творців, стильовими або декоративними характеристиками.

Водночас поняття «особистість» трактується українськими психологами Г. Баллом і В. Мєдінцевим як втілення або буття культури у людському індивіді, певна якість особи, що дозволяє їй бути відносно автономним та індивідуально своєрідним суб'єктом культури [3, с.7-8]. Тож культуру можна вважати не тільки місцем перебування людини, а й сферою подальших перетворень особистості [4, с. 191]. Як свідчить дослідник Т. Сілаєва, з поняттям «особистість» пов'язана фундаментальна, істотна риса людини бути не просто залежною від суспільства, не просто пасивним продуктом обставин, а виступати суб'єктом, діючою істотою, якій притаманні свобода волі й вибору, 
а також здатність до творчості в усіх їі проявах $[9,162]$. Ще одне визначення вказаного поняття запропонував український науковець Я. Чорненький. Пояснюючи поняття «особистість» через поняття «людина», можна сказати, що особистість - це людина зі сформованим світоглядом, тобто, системою поглядів на світ, самосвідомістю й здатністю до творчої самореалізації через діяльність [12, 68]. Театральне мистецтво - вид мистецтва, особливістю якого є художнє відображення життя за допомогою сценічної дії акторів перед глядачами. Нідерландський вчений, дослідник культури Й. Хейзинга зазначає, що ствердження «весь світ - театр» достатньо обгрунтоване, адже досвід усвідомлення людиною себе та світу щедрий на театральні аналогії. I театр стає елементом ігрової сутності культури, однією з найдовершеніших форм гри $[10,159]$. Також в одному із найважливіших театральних маніфестів XX століття «На шляхах до убогого театру» відомий польський теоретик театру С. Гротовський зазначив, що у подальшому процесі розвитку театру людина буде не лише одним з елементів постановки, а й становитиме інтегральну цілість, в якій все зосереджуватиметься саме на акторі [6].

У культурології й досі немає чіткого визначення поняття «аматорський театр». Та можна стверджувати, що в культурологічній інтерпретації український аматорський театр - це культурна інституція, що творчістю любителів мистецтва сцени створює культуру у непрофесійному просторі мистецтва. Зближуючи мистецтво і повсякденне життя завдяки своїй відмінності від професійного театру, аматорство розповсюджує серед широкого загалу мистецькі цінності, несе естетичні смисли та сенси життя, транслює знаки культури, поширює традиції та надає світоглядно-моральні орієнтири поведінки індивіда у соціумі. Відтак аматорський театр виконує потужну культуротворчу функцію, забезпечуючи збереження, передачу, відтворення й розвиток української культури через людину «граючу», закладаючи у неї механізми культурної ідентифікації.

Визначення культуротворчості як складної системи, в якій відбувається творення культури й поза межами традиційної творчої діяльності, що характеризується й мотивується прагненням творчої особистості до досконалості й новаторства, яке дає Т. Добіна, також важливе в контексті цього дослідження. Завдяки здатності сучасного аматорського театру до культуротворення в його учасників формується сприйняття та усвідомлення свого звичного й природнього культурного буття в процесі постійної (зазвичай підсвідомої) інтроспекції, а входження в іншу культуру (адже кінець ХХ початок XXI століття характеризується взаємопроникненням різних культур), розуміння особливостей і самовизначеності потребує толерантності (співпереживання) й володіння методом універсальної інтерпретації (герменевтики) [7, с. 53-54]. Театр зближує мистецтво й життя, створюючи культуру в просторі буття, тож театральне мистецтво необхідно розглядати в ширшому філософському та соціокультурному контексті, оскільки театр, як культурний інститут, здатен надати певні орієнтири поведінки індивіда в соціумі, особливо в переломні моменти розвитку суспільства $[1$, 3-4].

Визначення методологічних підходів важливе для логічної побудови наукового дослідження, оскільки воно безпосередньо впливає на характер його результатів. У дослідженні українського аматорського театру методологічною основою має стати культурологічний підхід, що спиратиметься як на емпіричний матеріал, так і на загальнонаукові методи пізнання. Думається, найбільш грунтовне вивчення феномену українського аматорського театру в кінці XX - на початку XXI століття можна забезпечити, застосувавши такі підходи:

1) історико-культурний підхід, адже розглядати культуру як духовне багатство суспільства i внутрішнє надбання людини, що постійно прагне до пізнання істини, добра і краси, долаючи свою природну обмеженість, усвідомлюючи єдність із суспільством та іншими людьми, необхідно звертаючись до зв'язку минулого із майбутнім, історії та сучасності;

2) системний підхід, що дозволяе розглядати український аматорський театр у функціональній взаємодії його елементів із іншими матеріальними і духовними підсистемами культури, а також його динаміку й трансформації в кінці XX - на початку XXI століття;

3) міждисциплінарний підхід, адже театральне мистецтво можна досліджувати з боку різних наукових галузей (історії, філософії, психології, соціології, педагогіки тощо).

Методологічного значення набуває тлумачення понять «особистість», що розглядатиметься як інтегральна якість, яка набувається людиною під час свідомої діяльності у процесі залучення до соціальної взаємодії; «становлення» як процес формування в особистості певних соціальнопсихологічних характеристик; «театральне мистецтво» як складний системний соціокультурний феномен, елементи якого можуть суттєво вплинути на становлення особистості митця. Адже театральне мистецтво має основу, споріднену з ігровою природою творчої людини, його складовими 
$\epsilon$ технології акторської гри та режисерське втілення художнього задуму, які подібні до процесів рольового опанування особистістю механізмів соціальної взаємодії.

Серед загальнонаукових методів дослідження обираються хронологічний метод для аналізу діяльності і впливу аматорських театрів на суспільні процеси від витоків до сьогодення; історикопроцесуальний метод для вивчення шляхів розвитку й становлення організаційної, мистецької, суспільно-політичної та громадської роботи українських аматорських театрів; аксіологічний метод і метод аналогії для співставлення аматорського театру й соціальної дійсності; компаративний, кроскультурний методи та метод структуралізму для порівняння особливостей професійного й аматорського театрів, виявлення їх особливостей та відмінностей, адже поряд із домінантною культурою існують ії відгалуження, які теж відіграють роль у формуванні суспільної свідомості якщо український професійний театр можна вважати частиною магістральної культури, то український аматорський театр 3 його мобільністю, здатністю до ризику та епатажу у виборі репертуару, продукуванням нових ідей, стає іiї альтернативним відгалуженням; метод конкретизації для вивчення стану мистецької й культуротворчої діяльності аматорських театрів у зв'язку з певними умовами існування та історичного розвитку; герменевтичний метод - для дослідження трансляції національних традицій у аматорському театрі кінця XX - початку XXI століття та їх інтерпретації аматорськими театральними колективами; семіотичний метод - для аналізу знаково-символічної сторони творчості сучасних українських аматорських театрів.

Для остаточного формування методологічної основи дослідження українського аматорського театру кінця XX - початку XXI століття необхідно врахувати, що об'єктивний опис і гармонійне охоплення фактів можливі лише за умов урахування обставин, за яких ці знання у свій час були отримані. Період 1990-х років можна охарактеризувати як час становлення української державності та морально-естетичного ідеалу суспільства, докорінних змін у багатьох сферах життя, зокрема й у сфері культури. Середина 1990-х років стала періодом випробувань, коли йшли пошуки можливих шляхів існування професійного й аматорського театру [11]. У 2000-ні роки відбулось пожвавлення аматорського театрального руху. Театральне дійство 3 домінантною естетичною функцією стає художньою технологією гармонізації людського життя, що приводить до зміни природи його зв'язків та трансформації структури, коли актор і глядач, будучи символами двох художніх актів, створюють штучний простір вигаданої дійсності за зразком та всупереч навколишній дійсності. I в ідеальному світі театрально-художньої умовності засоби художньої виразності оптимізують процеси занурення та соціальної адаптації людини [8, с. 3-8].

Наукова новизна. Вперше в культурологічній інтерпретації дається визначення поняттю «аматорський театр» та розробляється методологія дослідження культуротворчої функції українського аматорського театру в кінці XX - на початку XXI століття.

Висновки. 3 огляду на суть викладеного вище, є підстави вважати, що методологічною основою дослідження культуротворчої функції українського аматорського театру та його ролі у становленні особистості митця в кінці XX - на початку XXI століття має бути системно-комплексний підхід, у контексті якого важливо з'ясувати культуротворчу функцію сучасного аматорського театру і виявити причинно-наслідкові зв'язки між процесом становлення особистості митця в сучасному суспільстві, що динамічно розвивається, та низкою інших фундаментальних утворень, що 3'являються під час вивчення проблеми. Отже, необхідно якомога повніше використати той методологічний потенціал, котрий накопичено протягом останніх десятиріч у галузі культурологічного знання, щоб проілюструвати здатність сучасного українського аматорського театру впливати на формування культури й становлення особистості завдяки можливості ретрансляції практичного культурного досвіду й критично осмисленій творчій реалізації особистості.

\section{Лimepamypa}

1. Абрашкевичус Г. А. Театральное пространство в системе современной культуры. Культурномистецьке середовище: творчість та технологіï: зб. матер. П’ятої Міжн. наук.-творчої конф. студентів, магістрантів, аспірантів та молодих вчених (10-11 листопада 2011 р., м. Київ). Київ: НАКККіМ, 2011. С. 3-5.

2. Ариарский М. А. Прикладная культурология: монография. Санкт-Петербург: Эго, 2001. 2-е изд., испр. и доп. $287 \mathrm{c}$.

3. Балл Г. О., Мєдінцев В. О. Особистість як індивідуальний модус культури і як інтегративна якість особи. Горизонти освіти. 2011. №3. С. 7-14.

4. Батракова С. Н. Методологические проблемы становления педагогического процесса формирования целостной личности. Мир психологии. 2004. №4. С. 183-193.

5. Герчанівська П. Е. Культурологія: термінологічний словник. Київ: НАКККіМ, 2015. 439 с. 